\title{
Rancang Bangun dan Uji Performansi Alat Pembuka Katup Menggunakan Mekanisme Tuas
}

\author{
${ }^{(1)^{*}}$ Leo Dedy Anjiu, ${ }^{(2)}$ Suhendra, ${ }^{(3)}$ Irma Fahrizal B.N. \\ (1),(2),(3) Jurusan Teknik Mesin, Politeknik Negeri Sambas, \\ Jl. Raya Sejangkung, Sambas, Kalimantan Barat \\ *Email:leodedyanjiu@yahoo.co.id
}

Diterima: 09.07.2021 Disetujui: 15.10.2021 Diterbitkan: 23.10.2021

\begin{abstract}
The increasing number of vehicles every year provides opportunities to vehicles service. Vehicle components that often serviced or overhaul is the valve mechanism. How to remove the valve from the cylinder head generally use a manual valve remove tool. The time required to remove the valve using the tools need a long time. Effort to overcome these problems is to modify the existing valve remove mechanism. The purpose of this research is to design and test the performance of valve remove using lever mechanism. Performance test was conducted to determine the press force value to remove the valve, the percentage increase performance and time to remove the valve. The main components of the valve remove tool using the lever mechanism is frame, table, pole support, locking, hand grips, hydraulic, lever pusher and shaft sled. Testing using the valve mechanism is contained in the cylinder head Toyota Kijang $4 K$. The valve remove tool design has a simple form, easy to make, cheap, but has very good performance. The smallest of the press force to remove the valve is $129 \mathrm{~N}$ obtained at a distance of lock and poles support as far as $22 \mathrm{~cm}$. The valve remove tool using the lever mechanism was design can remove the valve from the cylinder head in time 26,17 seconds/valve or 418,67 seconds to remove 16 valves on the cylinder head. This tool is able to improve the performance of manual valve remove tool screw type by $76,28 \%$, and can improve the performance valve remove tool the pneumatic system by $65,79 \%$.
\end{abstract}

Keywords : valve mechanism, valve remove, performance test

\begin{abstract}
ABSTRAK
Meningkatnya jumlah kendaraan bermotor setiap tahun memberikan peluang pada layanan jasa servis kendaraan. Komponen kendaraan bermotor yang sering diservis atau dibongkar diantaranya adalah mekanisme katup. Cara melepas katup dari kepala silinder umumnya menggunakan alat bantu pembuka katup manual. Waktu yang diperlukan untuk melepas katup menggunakan alat pembuka katup manual relatif lama. Upaya untuk mengatasi permasalahan tersebut adalah melakukan modifikasi mekanisme alat pembuka katup yang telah ada. Tujuan penelitian ini adalah melakukan rancang bangun dan uji performansi terhadap alat pembuka katup menggunakan mekanisme tuas. Uji performansi dilakukan untuk mengetahui besar gaya tekan untuk membuka katup, persentase kenaikan performansi dan waktu membuka katup. Komponen utama alat pembuka katup menggunakan mekanisme tuas ini adalah rangka, meja, tiang penyangga, pengunci, hand grip, hidrolik, tuas penekan dan poros peluncur. Pengujian menggunakan mekanisme katup yang terdapat pada kepala silinder Toyota Kijang 4K. Alat pembuka katup hasil rancang bangun memiliki bentuk sederhana, mudah dibuat, murah, namun memiliki kinerja sangat baik. Gaya tekan terkecil yang diperlukan untuk melepas katup adalah $129 \mathrm{~N}$ yang diperoleh pada jarak pengunci dari tiang penyangga sejauh $22 \mathrm{~cm}$. Alat pembuka katup menggunakan mekanisme tuas hasil rancang bangun dapat melepas katup dari kepala silinder dalam waktu 26,17 detik/katup atau 418,67 detik untuk membuka 16 katup pada kepala silinder. Alat ini mampu meningkatkan performasi alat pembuka katup manual tipe ulir sebesar $76,28 \%$, serta dapat meningkatkan performasi alat penekan pegas katup sistem pneumatik sebesar $65,79 \%$.
\end{abstract}

Kata Kunci : mekanisme tuas, pembuka katup, uji performansi 


\section{Pendahuluan}

Kendaraan bermotor merupakan salah satu kebutuhan yang memiliki peran penting dalam menunjang aktivitas manusia. Kendaraan bermotor dapat mendukung mobilitas dan sebagai sarana angkutan bagi masyarakat yang termasuk bagian dari sistem transportasi. Pentingnya kendaraan bermotor terlihat dari meningkatnya jumlah penggunaan kendaraan bermotor setiap tahunnya di Indonesia.

Berdasarkan data Badan Pusat Statistik (BPS, 2019), jumlah total kendaraan bermotor di Indonesia pada tahun 2019 mencapai 133.617.012 unit yang terdiri dari sepeda motor 112.771.136 unit, mobil penumpang 15.592.419 unit, mobil barang 5.021.888 unit dan mobil bis 231.569 unit. Jumlah penggunaan kendaraan bermotor mengalami kenaikan sebesar 5,62\% dari tahun sebelumnya. Jumlah kendaraan bermotor diprediksi akan terus mengalami peningkatan sejalan dengan pertambahan penduduk.

Meningkatnya jumlah kendaraan bermotor dapat memberikan dampak positif dan negatif. Bagi layanan jasa servis kendaraan, hal tersebut merupakan peluang yang dapat dimanfaatkan. Jumlah kendaraan yang semakin banyak memungkinkan kebutuhan layanan jasa servis kendaraan semakin diperlukan.

Komponen kendaraan bermotor yang sering mengalami kerusakan dan sering diservis diantaranya adalah engine. Perbaikan pada engine dilakukan dengan memeriksa, melakukan overhaul, atau mengganti komponen engine. Mekanisme yang sering dibongkar dalam overhaul engine adalah mekanisme katup. Mekanisme katup terdiri dari beberapa komponen yang terletak di bagian kepala silinder.

Mekanisme katup terdiri dari pegas katup, katup, batang penekan, dudukan katup, penghantar katup, pengangkat katup, chamshaf dan rocker arm (Prasetya, 2009). Katup dalam sebuah engine berperan untuk mengatur aliran campuran bahan bakar yang masuk ke dalam ruang bakar (Rahman, Wigraha, \& Widayana, 2017).

Kerusakan yang sering dialami mekanisme katup adalah keausan pada katup (Zami, 2010). Kerusakan tersebut menyebabkan terjadinya berbagai gangguan pada kendaraan antara lain tekanan kompresi ruang bakar lemah, kendaraan mengeluarkan asap putih, pemakaian oli boros dan mesin sulit dinyalakan (Najib, 2013). Kerusakan pada mekanisme katup secara umum disebabkan adanya kontak, gesekan dan tumbukan yang terjadi terusmenerus saat mekanisme katup beroperasi (Saifurrijal, 2009).

Kegiatan melepas katup dari kepala silinder umumnya menggunakan alat bantu pembuka katup manual baik yang menggunakan sistem ulir atau menggunakan sistem tekan manual. Waktu yang diperlukan untuk melepas katup menggunakan alat bantu pembuka katup manual adalah 1,5 - 2 menit/katup atau diperlukan waktu sekitar 24 32 menit untuk melepas satu set katup dari kepala silinder sebuah mobil yang memiliki 16 katup (Mulyono et al., 2016). Kecepatan dalam melepas katup juga dipengaruhi oleh keahlian menggunakan alat pembuka katup.

Efisiensi waktu melepas katup dari kepala silinder dapat ditingkatkan dengan melakukan modifikasi pada alat bantu pembuka katup. Upaya yang telah dilakukan diantaranya telah dirancang bangun alat penekan pegas katup sistem pneumatik yang dilengkapi dengan penopang kepala silinder (Mulyono et al., 2016). Berdasarkan hasil pengujian, alat ini mampu meningkatkan efisiensi waktu melepas katup sebesar $50 \%$ berbanding menggunakan alat pembuka katup manual. Namun alat ini masih memiliki banyak kelemahan antara lain sistem instalasi rumit, bentuk relatif besar, kurang ergonomis dan biaya pembuatan mahal.

Berdasarkan kondisi tersebut, diperlukan upaya untuk memperbaiki sistem pembuka katup dengan merancang bangun dan memodifikasi alat pembuka katup yang telah ada. Modifikasi berperan untuk meningkatkan kinerja alat, mempermudah proses pelepasan katup, dan mengurangi penggunaan tenaga dalam mengoperasikan alat.

Konsep yang digunakan dalam rancang bangun alat pembuka katup ini memanfaatkan prinsip sederhana tuas. Tuas berperan untuk memperkecil gaya tekan saat melepas katup dan mempermudah posisi tubuh sehingga lebih nyaman saat menekan. Pengoperasian alat ini masih dilakukan secara manual menggunakan tenaga manusia.

Tujuan penelitian ini adalah melakukan rancang bangun dan uji performansi terhadap 
alat pembuka katup menggunakan mekanisme tuas. Rancang bangun alat pembuka katup ini juga mempertimbangkan konsep teknologi tepat guna yaitu mudah dibuat, mudah digunakan dan murah sehingga dapat digunakan untuk memecahkan permasalahan di masyarakat.

\section{Bahan dan Metode}

\subsection{Waktu dan Tempat Pelaksanaan}

Pembuatan dan pengujian alat pembuka katup menggunakan mekanisme tuas dilakukan di bengkel Jurusan Teknik Mesin Politeknik Negeri Sambas. Pelaksanaan kegiatan penelitian dimulai dari bulan Maret sampai dengan Juli 2020.

\subsection{Tahapan Penelitian}

Tahapan pelaksanaan penelitian dapat dilihat pada diagram alir Gambar 1.

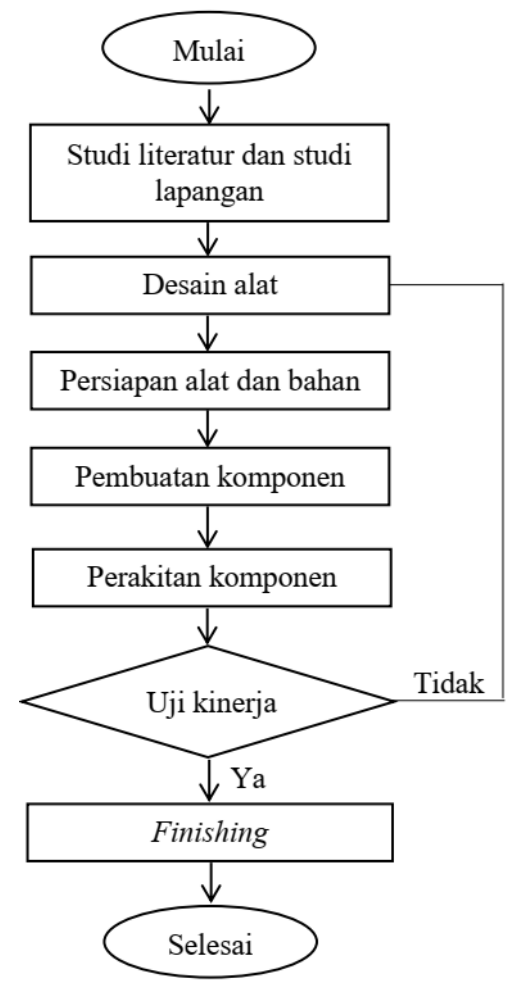

Gambar 1. Tahapan pelaksanaan penelitian

\subsection{Gambar Desain}

Desain awal alat pembuka katup yang akan dibuat dapat dilihat pada Gambar 2 . Komponen utama alat pembuka katup menggunakan mekanisme tuas adalah rangka, meja dudukan, tiang penyangga, pengunci, handgrip, hidrolik, tuas penekan dan poros peluncur.
1. Rangka

Rangka berfungsi sebagai penahan dan tempat dudukan berbagai komponen lainnya

2. Meja dudukan

Meja dudukan berfungsi sebagai tempat dudukan kepala silinder.

3. Tiang penyangga

Tiang penyangga berfungsi sebagai dudukan tuas penekan dan tempat untuk mengunci hidrolik.

4. Pengunci

Pengunci berfungsi membuka pin yang berada diatas daun katup.

\section{Handgrip}

Handgrip berfungsi sebagai pengaman tangan saat proses penekanan tuas serta untuk memberikan kenyamanan saat menggunakan alat.

6. Hidrolik

Hidrolik berfungsi mengembalikan tuas penekan ke posisi semula setelah menekan katup.

7. Tuas penekan

Tuas penekan berfungsi sebagai penekan, dudukan poros peluncur dan sebagai tempat handgrip.

8. Poros peluncur

Poros peluncur berfungsi mengatur maju mundurnya pengunci pada tuas penekan dan sebagai dudukan pengunci.

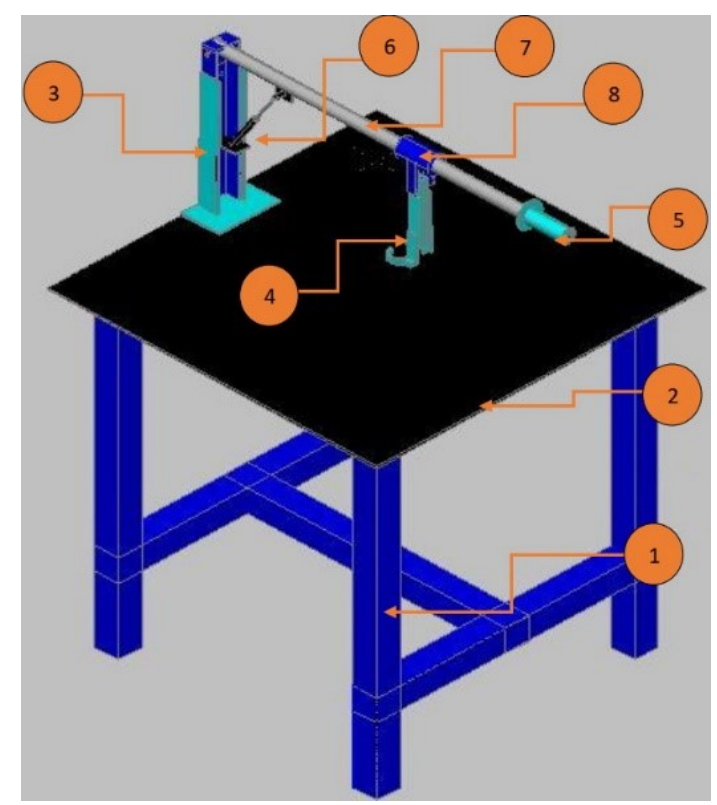

Gambar 2. Desain alat pembuka katup 


\subsection{Alat dan Bahan}

Alat yang digunakan dalam proses pembuatan alat pembuka katup ini adalah mesin las, mesin bor duduk, mesin bor milling, mesin bubut, mesin gerinda, penggaris, tab, siku, penggores, palu, ragum siku, set kunci ring pas, topeng las, apron, sarung tangan las, kacamata las, amplas kasar, amplas halus dan kompresor.

Bahan utama yang digunakan dalam proses pembuatan alat ini adalah besi UNP 65 x $42 \times 5 \mathrm{~mm}$, besi UNP $50 \times 38 \times 5 \mathrm{~mm}$, besi hollow $5 \times 5 \mathrm{~cm}$, pelat $4 \mathrm{~mm}$, pipa galvanis berdiameter $2,5 \mathrm{~cm}$, pipa besi berdiameter 35 $\mathrm{mm}$, handgrip, hidrolik, mur dan baut.

\subsection{Pembuatan dan Perakitan Komponen}

1. Pembuatan rangka

Rangka dibuat dari bahan besi hollow $5 \times 5$ $\mathrm{cm}$, disambung dengan cara dilas. Ukuran panjang, lebar dan tinggi rangka adalah masing-masing $60 \times 60 \times 70 \mathrm{~cm}$.

2. Pembuatan meja

Meja sebagai tempat dudukan terbuat dari pelat besi $4 \mathrm{~mm}$, berukuran panjang dan lebar $70 \times 70 \mathrm{~cm}$. Penyambungan meja dudukan pada rangka dilakukan dengan cara dilas.

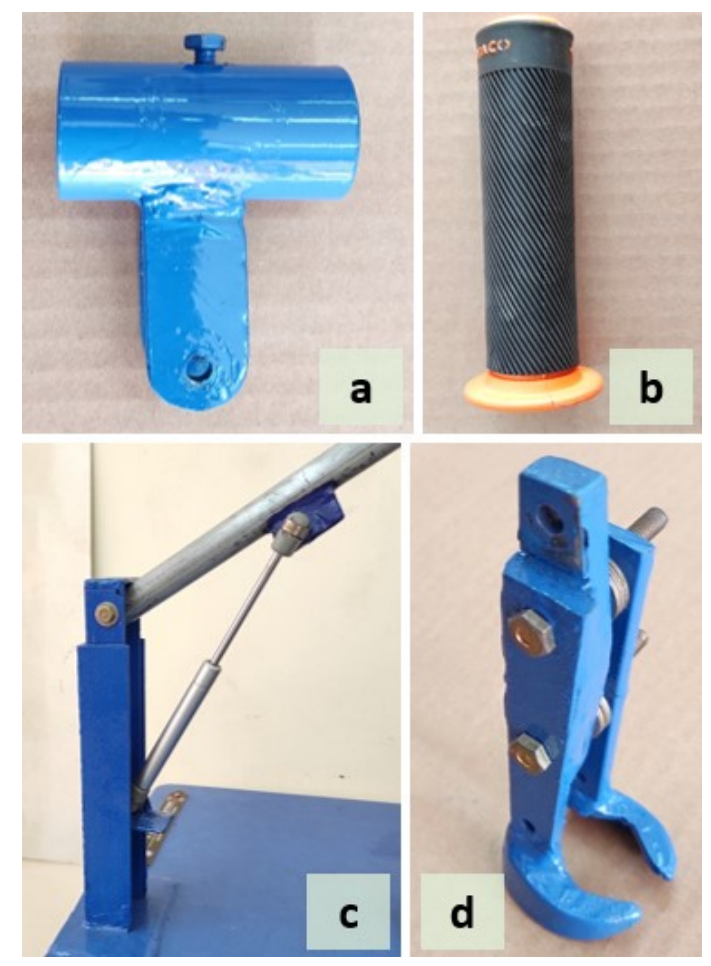

Gambar 3. Komponen alat pembuka katup, (a) poros peluncur, (b) handgrip, (c) hidrolik, tiang penyangga dan tuas penekan (d) pengunci
3. Pembuatan tiang penyangga

Tiang penyangga terbuat dari besi UNP ukuran $65 \times 42 \times 5 \mathrm{~mm}$ yang dipotong sepanjang $29 \mathrm{~cm}$ dan besi UNP 50 × 38 x 5 $\mathrm{mm}$ yang dipotong sepanjang $24 \mathrm{~cm}$. Bor potongan profil $\mathrm{U}$ yang panjangnya 24 dengan mata bor $8 \mathrm{~cm}$ dan las tiang penyangga pada meja.

4. Pengunci

Pengunci dibuat dari pelat $4 \mathrm{~mm}$, memiliki tinggi $10 \mathrm{~cm}$ dan disambung pada poros peluncur menggunakan baut.

5. Tuas Penekan

Tuas penekan dibuat dari pipa galvanis berdiameter $2,5 \mathrm{~cm}$ yang dipotong sepanjang $75 \mathrm{~cm}$.

6. Poros peluncur

Poros peluncur terbuat dari bahan pipa besi berdiameter $35 \mathrm{~mm}$. Poros peluncur dibuat dengan panjang $7 \mathrm{~cm}$, bagian bawahnya dibuat penahan yang berfungsi sebagai dudukan pengunci.

\subsection{Pengujian Alat}

Pengujian bertujuan untuk melihat apakah alat yang telah dirancang bangun dapat bekerja dengan baik, serta seberapa besar persentase kenaikan performansi penggunaan alat dibanding teknik melepas katup menggunakan alat manual atau alat penekan pegas katup sistem pneumatik yang telah dirancang bangun sebelumnya.

Persentase kenaikan performansi dihitung berdasarkan waktu yang diperlukan untuk melepas katup dari kepala silinder. Waktu yang dihitung adalah waktu total yang diperlukan termasuk waktu menekan pegas, waktu melepas katup dan waktu untuk menggeser posisi kepala silinder.

Persentase kenaikan performansi alat pembuka katup menggunakan mekanisme tuas ini dapat dihitung menggunakan persamaan 1 berikut (Suhendra \& Nopriandy, 2018).

$$
\mathrm{PP}=\frac{t_{1}-t_{2}}{t_{1}}(\%)
$$

Keterangan :

$\mathrm{PP}=$ Persentase kenaikan performansi (\%)

$t_{l}=$ Waktu membuka katup menggunakan alat pembanding (detik)

$t_{2}=$ Waktu membuka katup menggunakan alat yang dirancang bangun (detik) 
Pengujian juga dilakukan dengan memvariasikan tinggi tiang penyangga dan jarak pengunci dari tiang penyangga untuk mengetahui besarnya gaya tekan yang diperlukan untuk melepas katup dari kepala silinder. Setiap kombinasi perlakuan dilakukan pengujian sebanyak 5 kali pengulangan.

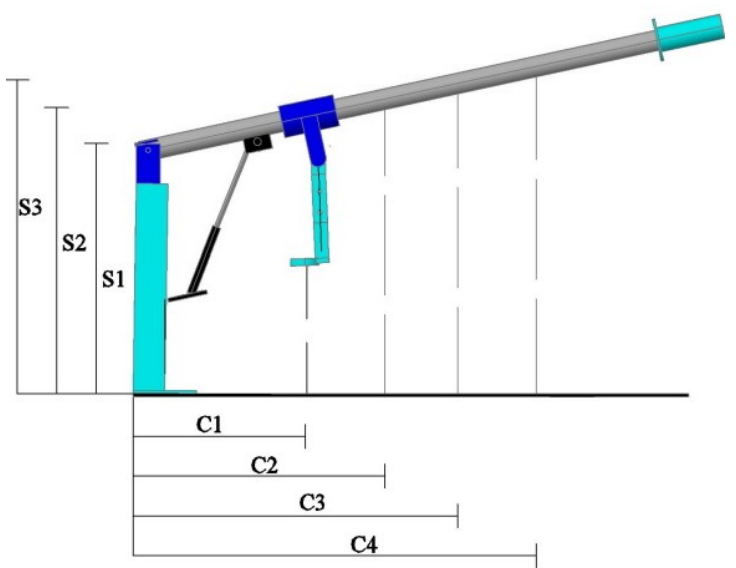

Gambar 4. Posisi pengujian alat untuk membuka katup

Keterangan :

$\mathrm{S}=$ Tinggi tiang penyangga terhadap meja

$\mathrm{C}=$ Jarak pengunci dari tiang penyangga
$\mathrm{C} 1=22 \mathrm{~cm}$
$\mathrm{S} 1=27 \mathrm{~cm}$
$\mathrm{C} 2=29 \mathrm{~cm}$
$\mathrm{S} 2=30 \mathrm{~cm}$
$\mathrm{C} 3=36 \mathrm{~cm}$
$\mathrm{S} 3=33 \mathrm{~cm}$
$\mathrm{C} 4=43 \mathrm{~cm}$

\section{Hasil dan Pembahasan}

\subsection{Hasil Rancang Bangun}

Hasil rancang bangun dan spesifikasi alat pembuka katup menggunakan mekanisme tuas dapat dilihat pada Gambar 5 dan Tabel 1 berikut.

Tabel 1. Spesifikasi alat pembuka katup hasil rancang bangun

\begin{tabular}{lll}
\hline No & Komponen & \multicolumn{1}{c}{ Spesifikasi } \\
\hline 1 & Dimensi (PxLxT) & $\begin{array}{l}70 \mathrm{~cm} \mathrm{x} 70 \mathrm{~cm} \mathrm{x} \mathrm{140} \\
\mathrm{cm}\end{array}$ \\
\hline 2 & Bobot alat & $\pm 15 \mathrm{~kg}$ \\
\hline 3 & Meja ( P x L ) & $\begin{array}{l}\text { Besi plat } 4 \mathrm{~mm}, \text { ukuran } \\
70 \mathrm{~cm} \times 70 \mathrm{~cm}\end{array}$ \\
\hline 4 & Handgrip & Karet \\
\hline 4 & Tuas penekan & $\begin{array}{l}\text { Pipa galvanis panjang } \\
75 \mathrm{~cm}\end{array}$ \\
\hline 5 & Hidrolik & 100 Newton \\
\hline
\end{tabular}

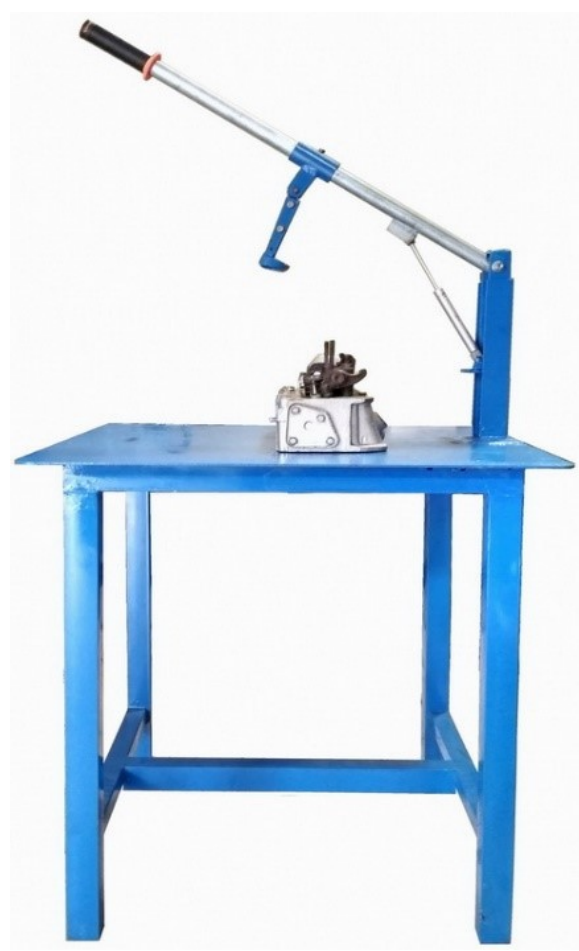

Gambar 5. Hasil rancang bangun alat pembuka katup menggunakan mekanisme tuas

\subsection{Hasil Pengujian}

Pengujian pada alat pembuka katup hasil rancang bangun dilakukan pada kepala silinder Toyota Kijang 4K. Hasil pengukuran mekanisme katup didapatkan data diameter pegas katup $30 \mathrm{~mm}$, tinggi pegas katup $44 \mathrm{~mm}$ dan panjang katup $100 \mathrm{~mm}$.

Data hasil pengujian besarnya gaya tekan yang diperlukan untuk melepas katup dari kepala silinder diperoleh dengan cara mengukur menggunakan neraca pegas. Neraca pegas tersebut dipasang pada tuas penekan dengan jarak tertentu. Neraca pegas yang telah terpasang pada tuas ditarik ke bawah sehingga tuas ikut menekan pegas katup. Data gaya tekan pada neraca pegas dicatat ketika katup lepas dari pegasnya. Data hasil pengujian dapat dilihat pada Tabel 2.

Tabel 2. Data hasil pengujian rata-rata besarnya gaya tekan untuk melepas katup

\begin{tabular}{ccccc}
\hline \multirow{2}{*}{$\begin{array}{c}\text { Tinggi } \\
\text { penyangga }\end{array}$} & \multicolumn{4}{c}{ Jarak pengunci } \\
\cline { 2 - 5 } & $\mathrm{C} 1$ & $\mathrm{C} 2$ & $\mathrm{C} 3$ & $\mathrm{C} 4$ \\
\hline S1 & 116,03 & 145,53 & 159,15 & 210,11 \\
S2 & 134,65 & 152,68 & 190,90 & 226,09 \\
S3 & 136,32 & 137,59 & 178,56 & 212,56 \\
\hline
\end{tabular}

Keterangan : satuan dalam Newton 


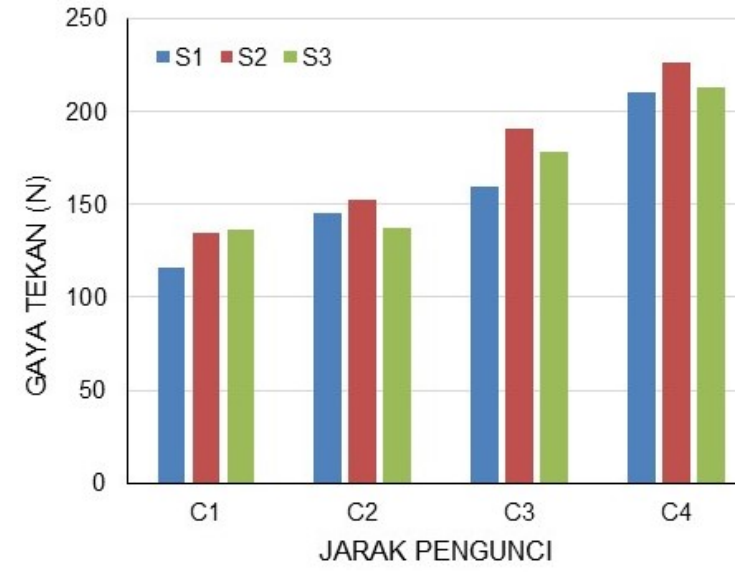

Gambar 6. Grafik hasil pengujian besarnya gaya tekan untuk melepas katup

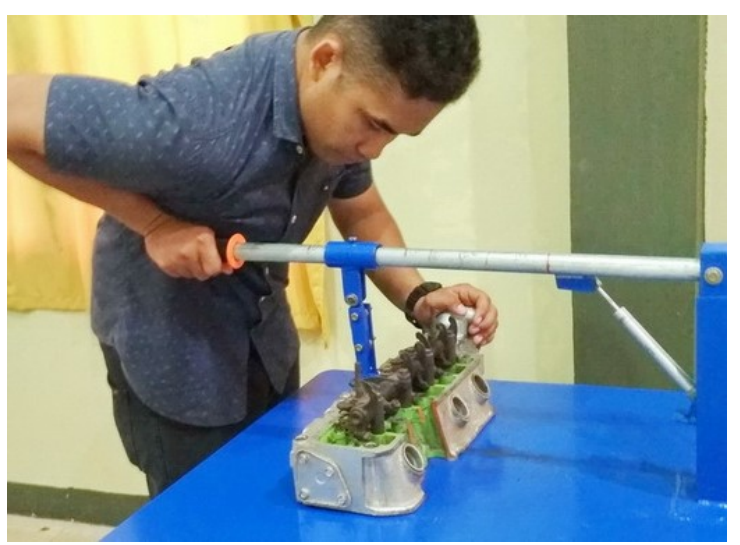

Gambar 7. Pengujian alat pembuka katup menggunakan kepala silinder Toyota Kijang $4 K$

Hasil pengujian menunjukkan bahwa ratarata gaya tekan terkecil yang diperlukan untuk melepas katup pada jarak pengunci dari tiang penyangga sejauh $22 \mathrm{~cm}$ (posisi $\mathrm{C} 1$ ) adalah $129 \mathrm{~N}$, sedangkan gaya tekan terbesar pada jarak pengunci dari tiang penyangga sejauh 43 $\mathrm{cm}$ (posisi C4) sebesar 216,25 N. Penggeseran posisi jarak pengunci yang semakin jauh dari tiang penyangga menyebabkan gaya tekan yang diperlukan untuk melepas katup semakin besar.

Data hasil pengujian terhadap waktu yang diperlukan untuk melepas katup dari kepala silinder menggunakan alat pembuka katup hasil rancang bangun dapat dilihat pada Tabel 3. Pengujian dilakukan pada jarak pengunci dari tiang penyangga $36 \mathrm{~cm}$ dan tinggi tiang penyangga terhadap meja $27 \mathrm{~cm}$.

Berdasarkan hasil pengujian, diperoleh bahwa rata-rata waktu yang diperlukan untuk melepas katup dari kepala silinder adalah 26,17 detik/katup atau 418,67 detik untuk membuka 16 katup pada kepala silinder
Toyota Kijang 4K. Hasil pengujian ini menunjukkan bahwa waktu untuk melepas katup menggunakan alat pembuka katup hasil rancang bangun lebih cepat dari alat pembuka katup manual atau alat penekan pegas katup sistem pneumatik. Alat pembuka katup manual tipe ulir membutuhkan waktu 1.765 detik, sedangkan alat penekan pegas katup sistem pneumatik membutuhkan waktu 1.224 detik untuk membuka 16 katup pada kepala silinder (Mulyono et al., 2016).

Tabel 3. Data hasil pengujian terhadap waktu untuk melepas katup dari kepala silinder

\begin{tabular}{clc}
\hline \multirow{2}{*}{ Pengujian } & 1 katup & 16 katup \\
\cline { 2 - 3 } & \multicolumn{2}{c}{ Waktu (detik) } \\
\hline 1 & 27,16 & 434,56 \\
2 & 27,20 & 435,20 \\
3 & 29,15 & 466,40 \\
4 & 28,25 & 452,00 \\
5 & 27,37 & 437,92 \\
6 & 24,80 & 396,80 \\
7 & 22,77 & 364,32 \\
8 & 28,24 & 451,84 \\
9 & 22,45 & 359,20 \\
10 & 24,28 & 388,48 \\
\hline Rata-rata & 26,17 & 418,67 \\
\hline
\end{tabular}

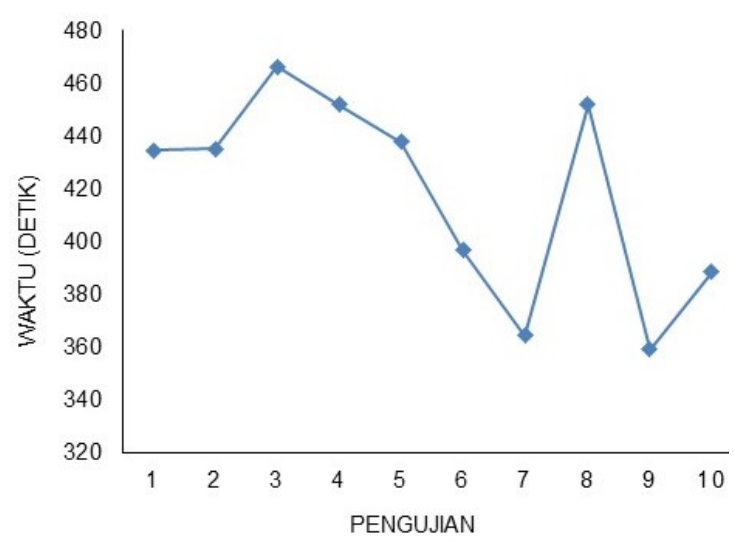

Gambar 8. Grafik hasil pengujian waktu untuk melepas 16 katup dari kepala silinder

Hasil pengujian ini menunjukkan terdapat peningkatan performansi kinerja menggunakan alat pembuka katup hasil rancang bangun. Peningkatan persentase performansi dapat dihitung menggunakan persamaan 1 .

1. Persentase peningkatan performansi alat pembuka katup hasil rancang bangun berbanding alat pembuka katup manual tipe ulir. 


$$
\begin{aligned}
& \mathrm{PP}=\frac{t_{1}-t_{2}}{t_{1}} \\
& \mathrm{PP}=\frac{1.765-418,67}{1.765} \\
& \mathrm{PP}=76,28 \%
\end{aligned}
$$

Data $t_{1}$ diperoleh dari waktu yang diperlukan alat pembuka katup manual tipe ulir untuk melepaskan 16 katup pada kepala silinder Toyota Kijang 4K yaitu sebesar 1.765 detik. Data $t_{2}$ diperoleh dari waktu untuk melepaskan 16 katup pada kepala silinder Toyota Kijang 4K menggunakan alat pembuka katup hasil rancang bangun. Nilai $t_{2}$ sebesar 418,67 detik dapat dilihat pada Tabel 3 .

2. Persentase peningkatan performansi alat pembuka katup hasil rancang bangun berbanding alat penekan pegas katup sistem pneumatik.

$$
\begin{aligned}
& \mathrm{PP}=\frac{t_{1}-t_{2}}{t_{1}} \\
& \mathrm{PP}=\frac{1.224-418,67}{1.224} \\
& \mathrm{PP}=65,79 \%
\end{aligned}
$$

Data $t_{1}$ diperoleh dari waktu yang diperlukan alat penekan pegas katup sistem pneumatik untuk melepaskan 16 katup pada kepala silinder Toyota Kijang 4K yaitu sebesar 1.224 detik. Nilai $t_{2}$ diperoleh dari alat pembuka katup hasil rancang bangun.

Hasil uji performansi menunjukkan terjadi peningkatan yang sangat signifikan terhadap waktu yang dibutuhkan untuk melepas katup pada kepala silinder berbanding alat yang sudah ada. Hal ini membuktikan bahwa alat pembuka katup menggunakan mekanisme tuas ini dapat berfungsi dan memiliki performa sangat baik.

Alat pembuka katup ini memiliki bentuk yang relatif sederhana sehingga sangat mudah dibuat. Selain itu, bahan yang digunakan untuk merancang bangun alat banyak tersedia di pasaran, dengan biaya total pembuatan alat tergolong murah.

Pengoperasian alat ini dilakukan secara manual dengan cara menekan tuas menggunakan tangan untuk melepas katup. Alat ini didesain agar berat tubuh dapat dimanfaatkan untuk membantu menekan tuas.
Dengan demikian, tenaga yang digunakan untuk menekan tuas dapat diminimalkan.

\section{Kesimpulan}

Berdasarkan hasil penelitian yang telah dilakukan, dapat dibuat beberapa kesimpulan sebagai berikut :

1. Alat pembuka katup menggunakan mekanisme tuas ini didesain memiliki bentuk sederhana, mudah dibuat, bahan untuk pembuatan mudah diperoleh, biaya pembuatan murah, namun memiliki kinerja sangat baik.

2. Hasil pengujian menunjukkan bahwa ratarata gaya tekan terkecil yang diperlukan untuk melepas katup adalah $129 \mathrm{~N}$ pada jarak pengunci dari tiang penyangga $22 \mathrm{~cm}$, sedangkan gaya tekan terbesar adalah 216,25 N diperoleh pada jarak pengunci dari tiang penyangga $43 \mathrm{~cm}$.

3. Alat pembuka katup hasil rancang bangun dapat melepas katup dari kepala silinder dalam waktu 26,17 detik/katup

4. Terdapat peningkatan performansi alat pembuka katup hasil rancang bangun berbanding alat pembuka katup manual tipe ulir sebesar 76,28\%, dan peningkatan performansi berbanding alat penekan pegas katup sistem pneumatik sebesar $65,79 \%$.

\section{Daftar Pustaka}

BPS. (2019). Perkembangan Jumlah Kendaraan Bermotor Menurut Jenis. Retrieved from https://www.bps.go.id/indicator/17/57/1/j umlah-kendaraan-bermotor.html

Mulyono, R. S., Jatiarso, W., Anjasmara, F., Achyar, G. F., Ardhiansyah, R., \& Pratama, A. (2016). Rancang Bangun Alat Penekan Pegas Katup Sistem Pneumatik dan Penopang Cylinder Head. Politeknologi, 15(3), 257-262.

Najib, I. (2013). Mekanisme Katup pada Mesin Suzuki G15. Jurusan Teknik Mesin, Fakultas Teknik, Universitas Negeri Semarang, Semarang.

Prasetya, F. D. (2009). Analisis Sistem Mekanisme Katup pada Toyota Kijang $5 K$. Jurusan Teknik Mesin, Fakultas Teknik, Universitas Negeri Semarang. 
Rahman, M. D., Wigraha, N. A., \& Widayana, G. (2017). Pengaruh Ukuran Katup Terhadap Torsi dan Daya pada Sepeda Motor Honda Supra Fit. Jurnal Pendidikan Teknik Mesin Undiksha, 5(3), 45-54.

Saifurrijal. (2009). Analisis Mekanisme Katup, Trouble Shooting dan Variasi Celah Katup Masuk terhadap Konsumsi Bahan Bakar pada Isuzu C190. Jurusan Teknik Mesin, Fakultas Teknik, Universitas Negeri Semarang.

Suhendra, S., \& Nopriandy, F. (2018). Analisis Penggunaan Batu Serpih sebagai Media Penyimpan Panas pada Kolektor Surya. Turbo, 7(2), 125-132.

Zami, Z. (2010). Analisa Valve dan Kerusakannya. Suara Teknik, 1(2), 7076.

https://doi.org/10.29406/stek.v1i2.399 